Abstracta Iranicacta Iranica

Revue bibliographique pour le domaine irano-aryen

Volume 32-33 | 2013

Comptes rendus des publications de 2009-2010

\title{
Tracey Sweek, St John Simpson. An unfinished Achaemenid sculpture from Persepolis
}

\section{Carlo Lippolis}

\section{Q OpenEdition \\ 1 Journals}

\section{Electronic version}

URL: http://journals.openedition.org/abstractairanica/40430

DOI: 10.4000/abstractairanica.40430

ISSN: 1961-960X

Publisher:

CNRS (UMR 7528 Mondes iraniens et indiens), Éditions de l'IFRI

\section{Printed version}

Date of publication: 1 December 2013

ISSN: 0240-8910

\section{Electronic reference}

Carlo Lippolis, "Tracey Sweek, St John Simpson. An unfinished Achaemenid sculpture from Persepolis ", Abstracta Iranica [Online], Volume 32-33 | 2013, document 124, Online since 01 July 2016, connection on 04 October 2020. URL : http://journals.openedition.org/abstractairanica/40430 ; DOI : https:// doi.org/10.4000/abstractairanica.40430

This text was automatically generated on 4 October 2020 .

Tous droits réservés 


\title{
Tracey Sweek, St John Simpson. An unfinished Achaemenid sculpture from Persepolis
}

\author{
Carlo Lippolis
}

\section{REFERENCES}

Tracey Sweek, St John Simpson. « An unfinished Achaemenid sculpture from Persepolis ", in : D. Saunders, ed., British Museum. Technical Research Bulletin 3. 2009, p. 83-88.

1 This article dwells on a relief that, from the external facade of the Apadana's north staircase, shows two grooms, the one finished and the other not. This relief, discovered in 1811, is subjected to a technical and interdisciplinary study of the carvings on the two parts of the slab. Insights are provided into the sequence of carving Achaemenid reliefs, the tools used at each stage, and the relation between a rigid plan and the sculptor's individuality. It would be worthwhile to compare these new findings with the previous studies on Achaemenid stonework and sculptors by Nylander, Tilia and Roaf. The sculpture (BM 1825, 0421.4: ME 118839) is only one among the several unfinished carvings from Persepolis. The authors suggest that the most obvious answer to explain why they remained incomplete might be the "vastness of the site and the magnitude of the task". These unfinished details were probably concealed under a layer of polychrome paint that was extensively applied on them. 


\section{AUTHORS}

\section{CARLO LIPPOLIS}

Università di Torino 